\title{
Tables
}

1 Negro population, percent of total population, and percent urban, by regions, United States, $1900-1950$..........

2 Japanese, Chinese, and Filipino populations in the United States, urban and rural, by regions and selected standard metropolitan areas, 1940 and $1950 \ldots \ldots \ldots \ldots \ldots \ldots$. $\ldots \ldots$.
istribution of Spanish-name population 1950 , by states, ur-

3 Distribution of Spanish-name population 1950, by states, urwith comparative data for the population of Spanish mother tongue, $1940 \ldots \ldots \ldots \ldots \ldots \ldots \ldots \ldots \ldots$

4 Nonwhite population by regions: observed, 1950; projected, 1975

5 Population in the United States, in standard metropolitan areas, in central cities, and outside central cities, by color: observed, 1950; estimated, 1956-1957; projected, $1975 \ldots$

6 Percent distribution of white and nonwhite population by types of areas; for selected cities, $1950 \ldots \ldots \ldots \ldots \ldots$.

7 Age, condition, and crowding of dwelling units in nonwhite versus white areas, for selected cities, $1950 \ldots \ldots \ldots \ldots$

8 Population change, 1940-1950, by color and categories of census tracts, for selected cities

9 Distribution of Chinese population in San Francisco, 1940

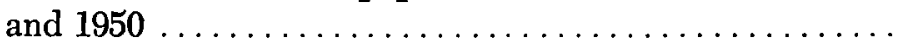

10 Distribution of nonwhite except Negro population in Man-

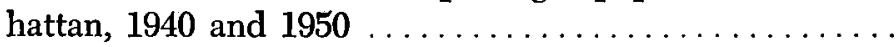

11 Median income of persons with income in 1949 , by race and ethnic group . 
12 White and nonwhite households by type, by tenure, for selected metropolitan areas, 1950

13 Percent changes in population and housing, by color of occupants, and population per occupied dwelling unit, United States, 1920-1956

14 Percent of occupied dwelling units substandard, 1950

15 Median number of rooms and percent of dwelling units crowded, by color of occupants, and for Spanish-name occupants, 1950

16 Percent of nonfarm households with 1.01 or more persons per room, United States, 1940 and 1950

17 Percent of nonfarm dwelling units crowded by condition and plumbing facilities, by color and tenure of occupants, for selected standard metropolitan areas, $1950 \ldots \ldots \ldots \ldots$

18 Median value and median gross rent of nonfarm ownerand tenant-occupied dwellings, for white, nonwhite, and Spanish-name white occupants: United States, selected states, and standard metropolitan areas, $1950 \ldots \ldots \ldots$.

19 Percent of renter-occupied dwelling units standard, by income and color of occupants, for selected metropolitan areas, 1950

ercent of owner-occupied dwelling units standard, by income and color of owner, for selected metropolitan areas, 1950

21 Percent of renter-occupied dwelling units with 1.01 or more persons per room, by income and color of occupants, for selected metropolitan areas, 1950

22 Percent of owner-occupied dwelling units with 1.01 or more persons per room, by income and color, selected metropolitan areas, 1950

23 Ratio of nonwhite to white median gross rents by income, for selected metropolitan areas, 1950

24 Ratio of nonwhite to white median market value of owneroccupied, single-unit properties by income, for selected metropolitan areas, 1950

25 Percent of renter-occupied dwelling units standard, by gross rent and color of occupants, for selected metropolitan areas, 1950 
26 Percent of owner-occupied single-unit dwellings standard, by market value and color of owner, for selected metropolitan areas, 1950

27 Paired comparisons of test and control area prices by percent of nonwhites in test area populations

28 Percent of properties mortgaged, by value and color of owner, United States, 1950

29 Percent distribution of mortgage loans by type and color of owner-occupants, United States, 1950 and 1956

30 Delinquency rates on first mortgages by color of owner, income, and type of mortgage, United States, 1950

31 States and cities with statutes, ordinances, or resolutions for nondiscrimination in housing, July, 1959

\section{Appendix Tables}

A-1 Percent distribution of population by color, and selected housing characteristics in urban areas of varying nonwhite concentration, for selected cities, $1950 \ldots \ldots \ldots$.

A-2 Residential concentration of nonwhites in selected cities, by census tracts, 1940 and 1950, and city of Los Angeles, 1956

A-3 Population changes in the city of Los Angeles, 1950-1956, by race, in census tracts classified by percent of population nonwhite in 1950

A-4 Comparative occupational distributions of employed workers by race (except Negro) and sex: United States, 1950

A-5 Condition and plumbing facilities of dwelling units by color and tenure of occupants, for the United States, urban and rural, and selected standard metropolitan

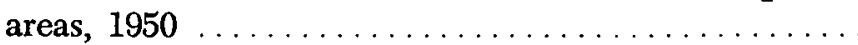

A-6 Median number of rooms in renter-occupied dwelling units by income and color of occupants, for selected metropolitan areas, $1950 \ldots \ldots \ldots \ldots \ldots \ldots \ldots \ldots$.

A-7 Median number of rooms in owner-occupied dwelling units by income and color of occupants, for selected metropolitan areas, 1950 
A-8 Median number of persons in renter-occupied dwelling units by income and color of occupants, for selected metropolitan areas, 1950

A-9 Median number of persons in owner-occupied dwelling units by income and color, for selected metropolitan areas, 1950

A-10 Median gross rent of renter-occupied dwelling units by income and color of occupants, for selected metropolitan areas, 1950

A-11 Median market value of owner-occupied, single-unit properties by income and color of owner, for selected metropolitan areas, 1950

A-12 Median number of rooms in renter-occupied dwelling units, by gross monthly rent and color of occupants, for selected metropolitan areas, $1950 \ldots \ldots \ldots \ldots \ldots \ldots$.

A-13 Median number of rooms in owner-occupied, single-unit properties by market value and color of owner, for selected metropolitan areas, 1950

\section{Figures}

1 Occupational distribution of employed workers in the United States, by race and sex, 1940, 1950, and $1958 \ldots \ldots \ldots .109$

2 Percent of persons who have completed at least four years of high school, United States, 1950 and 1957

3 Percent of occupied dwelling units substandard, selected metropolitan areas, $1950 \ldots \ldots \ldots \ldots \ldots \ldots \ldots \ldots \ldots .124$

4 Rented dwellings, percent standard by income and color ... 138

5 Owned dwellings, percent standard by income and color ... 138

6 Racial differences in median number of rooms, by income

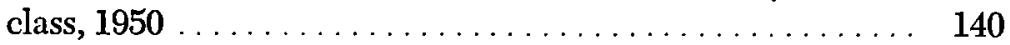

7 Rented dwellings, percent with 1.01 or more persons per room by income and color ..................... 141

8 Rented dwellings, percent standard by gross rent and color .. 151 